\title{
Elwood Murray: Innovator, Integrator, Educator
}

\author{
Judi Brownell
}

Cornell University

\begin{abstract}
A case study of Professor Elwood Murray was undertaken to reveal his impact both on his students and on the curriculum at the University of Denver. Interviews were conducted with Dr. Murray as well as with many of his former students and colleagues. Questionnaires were distributed and results compiled, catalogs from the Denver library were reviewed, and Murray's personal files were examined. Dr. Murray is seen to be an innovator who pioneered in the application of social science techniques to the speech classroom, and a man of vision who left a lasting impression on his students.
\end{abstract}

Key Concepts Elwood Murray, general semantics, integrator, methodology, speech personality, communication competence, classroom excellence, teacher scholar, communication pioneer.

Judi Brownell (PhD, Syracuse University, 1978) is Assistant Professor in the School of Hotel Administration, Cornell University, Ithaca, NY 14853. 
Elwood Murray: Innovator, Integrator, Educator

In 1970, three of Elwood Murray's colleagues from the University of Denver opened his festschrift, Language Behavior: A Book of Readings in Communication (1970), with a quotation by Issac Newton: "If I have seen farther than other men, it is because I have stood on the shoulders of giants." Indeed, those of us in the field of speech communication owe much to the labors and commitment of educators who have gone before us. These speech professionals have each had a unique and significant impact on their students and, often, on the discipline as well.

The purpose of this paper is to introduce Elwood Murray, an educator who, through his energy, conviction, and vision, has made a lasting contribution to speech communication education. A brief review of Dr. Murray's background and ideas provides a context for the reader to appreciate the environment in which he worked. Emphasis is then placed on the man himself as he influenced both the curriculum at the University of Denver and the students who studied in what was then one of the most nontraditional programs in speech communication.

\section{Background}

In the spring of 1929, Elwood Murray began his graduate work at the University of Iowa. It was here that he began to fully develop his ideas concerning the relationship between personality and speech as he worked with some of the giants of his time; among them, Charles H. Woolbert, A. received his PhD in speech with a minor in psychology, having written his dissertation under the direction of Lee Edward Travis.

Graduating in the middle of the depression, Murray accepted one of the few openings in speech that fall, an associate professorship at the University of Denver. The only account of the early years of the Department of Dramatic Arts and Speech appears to have been written by Elwood Murray himself for a special edition of Western speech in 1957. It is clear, however, that the years from 1931 to 1962, the period during which Elwood Murray chaired the Department of speech, saw vast changes both in the field of speech communication and in the curriculum at the University of Denver. Soon after assuming his faculty position, Murray began to apply his ideas concerning the link between speech and personality development. It was with considerable curiosity and skepticism that the speech profession responded in 1937 to Murray's most well-known book. The Speech Personality. The text was, above all else, designed to "make a difference" not 
only in the student's classroom performance but also in his ability to adjust appropriately to everyday social situations.

Dr. Murray believed that a well-adjusted personality was prerequisite to effective speech behavior. This mentallyobjective individual would then be prepared to function as a social integrator, a "critically-minded cooperator" and leader who would bring his fellowmen together around the important issues facing society. After his extensive study with Alfred Korzybski, ${ }^{1}$ Murray became convinced that the principles of general semantics were the means by which individuals might acquire the necessary objectivity and form habits of perception which would enable them to view their world relationally.

Integrative Speech (1953), Murray's second text, described at length the general semantics formulations which would assist in obtaining this objective, relational orientation. Although Charles $\mathrm{H}$. Woolbert is credited with first introducing Murray to a holistic view, it was Murray's work with Korzybski throughout the late 1930's and 1940's that gave direction and impetus to his theory. Many years later, with the introduction of cybernetic and general systems concepts, Murray was further stimulated to search for existing but unperceived relationships as they existed at all levels throughout the universe.

Always, Murray brought his theories and holistic perspective into the classroom. The courses in which The speech Personality was used were characterized by innovative methods and non-traditional theories. Instruction was individualized according to speech-personality needs, with projects assigned to help each student attain greater personal adjustment. ${ }^{2}$ Personal journals and work in the speech clinic were also a part of this offering. Senior speech majors were assigned as coaches for underclassmen, helping them prepare for their presentations. Murray strongly believed that only students who were well prepared should be allowed to perform, thus guaranteeing successful speech experiences.

Murray's reputation as a methodologist was further enhanced through his work with Kurt Lewin in the 1940's. This exposure led him to apply the principles of group dynamics well in advance of most speech educators.

Murray believed that sociodrama, too, was well suited for the difficult task of helping students internalize important communication behaviors and apply them to practical speech situations. ${ }^{3}$ 
While many of his colleagues were fighting to keep speech instruction confined to the platform, Murray was setting up the Laboratory in Interpersonal Communication. This laboratory, initiated in 1949 and thought to be the first of its kind, was a highly structured group experience that incorporated extensive feedback opportunities. Through group dynamics techniques, Murray believed the principles of general semantics could be understood and internalized. As a former student stated, Murray was a "man with a vision who saw something of great value and who brought it into academia... a man who understood the value of the original thinking and who was able to develop it in an academic context" (Washburn, 1977). Later, Murray's Interdisciplinary Analogue Laboratory brought together scholars from diverse disciplines in an effort to encourage relational thinking and interdisciplinary approaches to problem solving.

The University of Denver became known for its graduate program based largely on general semantics. The program, titled Communication Methodology, prepared students to apply the findings of social science research to man's everyday communication problems in education, industry, and other contexts. Throughout the 1960's, both in the summer programs and during the regular school semesters, general semantics continued to be the main focus of training in speech and Denver was distinguished as the only university granting the PhD in this area. The university had been recognized, too, for its progressive approaches in the field. As one department report stated (1965):

The speech department at the University of Denver has been a maverick in the past and may continue to act like a maverick in the future. . . . Being a maverick is both the strength and weakness of this department. We have pioneered under the direction of Elwood Murray in a freewheeling way and have now established ourselves as one of the important departments in the country for the student of general semantics and communication arts (p. 4).

Four years after his retirement from full time teaching, Elwood Murray received an Emeritus Professorship from the University of Denver. An anthology dedicated to the work he pioneered in communication methodology. Language Behavior, was initiated by $\mathrm{Dr}$. Johnnye Akin and contains original essays by some of the most well-known scholars in the field. The 
festschrift paid tribute to a man whose life had been dedicated to helping individuals become more effective communicators. ${ }^{4}$

A Man of Vision

We are constantly reminded that the difference between an average and a truly great teacher is frequently not a matter of subject knowledge, but rather some special, intangible quality which reveals itself in the classroom. After discussions with many of his former students, several distinguishing features of Professor Murray's instructional style and classroom management can be identified. Murray was a warm and sincere educator who had a positive regard for his students. Although difficult for some students to understand, Murray inspired those with a strong interest in communication and involved them in challenging classroom experiences. Perhaps of greatest impact, however, was his adventurous spirit, his energy, and his willingness to experiment with non-traditional approaches to the teaching of speech. This was a man of vision who encouraged his students to explore beyond the traditional boundaries of the speech field.

It is clear that Murray's students felt he had a sincere commitment to helping them understand the process of human communication. Students and colleagues alike point out that although he may have added to our theoretical understanding of general semantics and related disciplines, it was evident that "Murray was, at heart, a great teacher who could and would do other tasks but. . . desired most to be an instructor where he functioned as an inspiring teacher and superior educational leader" (Page, 1977). His enthusiasm for his subject was contagious, and his confidence in each student's ability to succeed created an atmosphere of trust and support. Alvin Goldberg, past chair of the Department of Speech Communication at the University of Denver, remarked that Murray relied almost entirely on positive feedback to motivate his students, finding something of value in even the most poorly written paper.

Murray's strength was not as a classroom lecturer. His explanations were often vague and his vocabulary specialized. Students had to be highly interested and self-motivated in order to follow his frequently abstract lectures. As one student wrote, "Anyone at all interested in learning about communication was challenged; anyone not interested was probably very confused" (Vaughn, 1977). Clearly, a period of adjustment was necessary before students were able to fully understand his presentations 
and the principles he discussed. Even this potential handicap, however, was viewed by some as a stimulus. Dr. Roy Wood, dean of the School of Speech at Northwestern University, had this to say:

The assignments were often confusing and incomplete but, I suspect, purposely so. . . . I'll give you an example of why I think that. The laboratory phase began when the groups were given written assignments. The assignments were vague, confusing, and apparently unrelated to the lectures. As a hotshot senior, I decided to help Professor Murray improve his course. I told him about the problem in communication he had and offered to do an independent study to rewrite and clarify each assignment for each session. He smiled and said, "Roy, it took me years to get them that way!"

Gail Myers, who has written several textbooks based on similar laboratory approaches (1976, 1982), commented on the same theme:

A professor who wants his students to learn . . . must permit all sorts of misevaluations from them-he must be willing to let his ego take a second place to the task at hand. He must be willing sometimes to be labelled disorganized, fuzzy. But the job gets done, and done better because eventually the student learns more, and sometimes even sheepishly realizes how he has been conned into getting an education.

Predictably, Murray's methodologies were emphasized as a factor in his classroom effectiveness. Students indicated that he provided their first exposure to the laboratory approach. Several stressed that Murray has received far too little recognition for pioneering laboratory work in interpersonal communication skills training. There was little question that his ability to apply group dynamics principles, feedback opportunities, and nondirective techniques in a classroom was exceptional. He had the ability to bring people together and serve as a catalyst, providing the atmosphere and opportunities for motivated students to undertake the ambitious objectives he outlined. The majority of Murray's students appreciated the open environment he created and recognized the freedom that characterized Denver's speech program during the 1940 's and 1950 's. As another student wrote (Touff, 1977):

He made us want to learn-he expanded our horizon in new areas. He encouraged us to read all the limited work available at 
that time. He was a very exciting guy-eager as a missionary-to me rather beautiful. He created in his group a real desire to know.

The term "missionary" appeared several times in student letters, describing Murray's dedication to his work. He was seen as flexible, open, and in constant search of new perspectives. Murray never hesitated to draw upon the methods and content of other disciplines if he believed they would contribute to the students' understanding of human communication. His seminars integrated sources and approaches from a number of fields. He was, his students agreed, a pioneer years ahead of his time. As Gordon Wiseman (1977) explained his view:

I went to Denver in 1952 to get my PhD because that was the place where new things were going on in the field of speech called communication and I was wanting to move in the "new direction". . . Dr. Elwood Murray was the pioneer in this field and as far as I am concerned had and still has the soundest approach.

When asked if Murray's work at Denver was viewed as different or nontraditional, Roy Wood (1977) responded:

. . there's no doubt that Elwood Murray was viewed as being nontraditional. I've discussed it with his peers, James McBurney for instance, and I'm certain he was always viewed as something of a maverick by his colleagues across the country. That was true when he was a debate coach in Iowa and Colorado. It was true when he became a general semanticist. And, it's true today .

Murray was considered nontraditional not only by his students, but by much of the Denver faculty and administration as well. Many faculty, even within his own department, found him difficult to understand and were unwilling to work with him. Dr. James Perdue noted that, when he was Dean of Liberal Arts at the University of Denver during the late 1950's, he spent considerable time keeping Elwood Murray out of trouble, protecting him from those who were less tolerant of his innovative ideas. One particularly revealing example of Murray's free spirit was presented by Donald Washburn (1977):

He drove this little Izetta-kind of a three-wheeleraround campus for awhile.... He was probably the only one who would dare get in one of those things. He would go zipping around. . . . It sort of symbolized his independence. He was willing to do what he thought needed to be done, and if something 
made sense to him, he did it. He didn't seem intimidated by establishments.

Elwood Murray was, as Donald Washburn continued, "a bit of a character. . . he had that twinkle in his eye. He was way out there, thinking thoughts that really weren't respectable in those days" (1977). Had Murray been seeking popularity, he would certainly not have chosen to hold fast to some of the theories he did, many of which fell for a time under heavy criticism. He was viewed by many as a rebel, a maverick, pursuing the scientific bases of speech which some believed was disrespectable and inappropriate. Elwood Murray was a "generalist in a community of specialists" (Johnson, 1978). Yet, he stood his ground firmly in the face of opposition and continued to work toward the goals he believed to be sound. The following passage by Gwenyth Vaughn (1977), one of Murray's former students, reflects this spirit:

Dr. Murray is, indeed, a "man before his time." He has dared to challenge myths; he has dared to dream of effecting a broad mix from many minds at many levels. Dr. Murray dares to be different. He continues to seek relationships in the vast world of science, art, music, language, and business.

The communication about all of these areas is a constant challenge and one that Dr. Murray is extraordinarily capable of grasping, analyzing, and presenting to those who are interested in listening. There are great futures for those who wish to follow his leadership in seeing the vast and beautiful world of interpersonal, interdisciplinary, and international communication.

In addition to his ability to bring together concepts from diverse fields, Murray's energy was another of his greatest personal strengths. When committed to a particular task, he would work relentlessly until its completion. The pioneering curriculum at the University of Denver is perhaps the best example of his untiring efforts. Donald Washburn described Murray as a man of "prodigious energy," and continued:

He was a hard worker. He worked, uninterruptedly, at his calling. He was always there in his office. . . he simply spent the time and energy that was needed to make things work. . . year in and year out effort. 
Carl Weaver recognized this same personal drive when he described Murray's role in the founding of the National Society for the Study of Communication in 1949. When Paul Bagwell became the organization's first president, he "turned to the man who was probably the best promoter in the group- Elwood Murray" (Weaver, 1974). Weaver described Murray's efforts:

President Bagwell wrote to Murray and asked him to assume the responsibility of organizing and implementing the various committees . . . Murray immediately began sending out from Denver what must have seemed to be a snowstorm of letters Every letter was a personal letter, explaining, asking, hoping. There were hundreds and hundreds of them.

Weaver continued:

It had been a long and arduous task, and it was not yet finished. Several more months passed until Murray was able to write to Ralph Nichols, the second president, and ask for a little time to rest. 'I am filled with a deep fatigue,' he wrote (p. 110).

Clearly, Elwood Murray demonstrated his commitment both to his students and to his profession. Even when his efforts were not recognized, Murray kept diligently to the task at hand. John Marshman (1955), in discussing the noteworthy educators he has known, made a statement that perhaps could be applied to Murray as well:

These were men. . . of vision, insight, and constancy . . . they had perspective in the whole field of speech as then known. Not many of them were burrowing scholars; there was no intellectual provincialism about them. They could see both the forest and the trees; to them the branches were a part of the tree. They made a rich and vital contribution to our speechtraining heritage ( $p .86)$.

In his teaching, Murray's interdisciplinary framework led his students outward into related fields where they could apply their knowledge of speech to education, business, international relations, the health and helping professions, and other fields of learning. Effective communication, when viewed as an integrating force, might serve as man's most important tool in organizing and guiding the development of his society. 
In Murray's view, communication was the most important and most basic human process. Unless knowledge was communicated, it could not contribute to the improvement of man and his society. The quality of man's communication would determine the quality of his life, and for this reason was his most valuable resource. Murray, then, was concerned not with communication as process alone, but also with the content and function of man's speech.

Murray had a vision, from his earliest days at Denver, of unifying the speech arts and sciences into a coherent discipline which would achieve the highest academic recognition. The means through which this integration could be accomplished gradually came to be seen as the symbolizing process, fundamental to all communicative behavior. Speech, as man's uniquely human ability, was what made all knowledge possible.

Focus on the communication process would serve to unify not only the field of speech but every discipline, for communication was the root of knowledge in all fields. To this end Murray worked to encourage others to think and perceive relationally, to integrate what they learned, to view themselves and their language behavior with increased objectivity so that healthy and productive outcomes would result. That his views were often unpopular and frequently misunderstood, that he was criticized from both within and outside of his own discipline, did not prevent Elwood Murray from channeling his full energies into what he believed to be his greatest challenge. It was this energy, this commitment, that enabled him to accomplish what he did. Such dedication was recognized by Andrew Weaver (1959) in his praise of the founding fathers of our national association when he wrote:

. . . we are prone to fall into the delusion that all our progress has been automatic and inevitable. When we are tempted to take our heritage for granted, we well may ponder the poignant words of George Washington, spoke as he mourned the death of his soldiers slain in a pathetic little raid to secure corn for their starving comrades: 'This liberty,' he said, 'will seem easy by and by when nobody has to die to get it.'

Weaver continued:

The history of mankind bears eloquent testimony to the fact that a mere handful of men who are 
obedient to a great vision can shake the world ( $p$ 199).

Elwood Murray followed a vision with much courage and consistency, and in the process many lives were enhanced. 


\section{Notes}

1. Elwood Murray was awarded some five scholarships to attend Alfred Korzybski's intense, two-week seminars at the General Semantics Institute. His first seminar was in August, 1939.

2. Part of Murray's course involved a diagnostic test and post test of each student's "speech personality." The MurrayMiller Personal Social Adjustment Test (1939) was most frequently used for this purpose.

3. Murray attended Kurt Lewin's National Laboratory in Croup Development during the summer of 1949, and subsequently incorporated these techniques into his speech courses.

4. The summer speech programs at the University of Denver attracted well-known scholars from throughout the country and brought the Department of speech and Dramatic Arts wide recognition. In 1932, the first annual Rocky Mountain Speech Conference was held, attended by forty institutions and representing some eight teachers and four hundred students. Continuing for over thirty years, this conference provided an opportunity for speech educators to share their thoughts on speech training. Among the contributors to these programs were Ralph Nichols, Jacob Moreno, Alfred Korzybski, and Lee Edward Travis. 


\section{$\underline{\text { References }}$}

Adams, B. (1971). Elwood Murray: A pioneer in speech communication. Unpublished master's thesis. Department of Speech and Theatre Arts, Brigham Young University.

Akin, J. et al. (Eds.). (1970). Language behavior: A book of readings in communication. The Hague, Paris: Mouton.

Brownell, J. (1979). Elwood Murray's interdisciplinary analogue laboratory. Communication Education 28 9-21.

Brownell, J. (1982). Elwood Murray's laboratory in interpersonal communication. Communication Education, 31, 325-332

Johnson, K. (1978, January). Letter to Judi Brownell.

Marshman, J. T. (1955). Trends in speech education in the last half century. The Speech Teacher, 4 79-86.

Murray, E., Barnard, R. \& Garland, J. (1953). Integrative speech. New York: The Dryden Press.

Murray, E. (1977, June). Interviews with Judi Brownell.

Murray, E. (1937). The speech personality. New York: J. B. Lippincott, Company .

Murray, E. Phillips, G. \& Truby, D. (1969). Speech: Science-art. New York: The Bobbs-Merril Company.

Murray, E. (1961). The University of Denver. Western Speech, 25, $79-80$.

Myers, G. \& Myers, M. T. (1976). The dynamics of human communication: A laboratory approach. New York: McGrawHill, Inc.

Myers, G. \& Myers, M. T. (1982). Managing by communication: An organizational approach. New York: McGraw-Hill, Inc.

Page, F, (1977, August). Letter to Judi Brownell, Report of the Denver speech retreat. (1965), Assumption number 2, 4,

Touff, D, S, (1977, September). Letter to Judi Brownell, Washburn, D, (1977, September). Tape recorded remarks from North Adams State College.

Weaver, A, T, (1959), Seventeen who made history-the founders of the association. The Quarterly Journal of Speech, 45, 195199.

Weaver, C, (1974). History of the international Communication Association. Unpublished manuscript commissioned by the International Communication Association, Wiseman, G, (1977, October). Letter to Judi Brownell. Wood, R, (1977, August). Letter to Judi Brownell. Vaughn, G. R, (1977, September), Letter to Judi Brownell. 